ARTICLE

DOI: $10.1038 / s 41467-018-04748-x$

\title{
Stable complete methane oxidation over palladium based zeolite catalysts
}

\author{
Andrey W. Petrov ${ }^{1,2}$, Davide Ferri ${ }^{1}$, Frank Krumeich ${ }^{2}$, Maarten Nachtegaal ${ }^{1}$, \\ Jeroen A. van Bokhoven ${ }^{1,2}$ \& Oliver Kröcher ${ }^{1,3}$
}

Increasing the use of natural gas engines is an important step to reduce the carbon footprint of mobility and power generation sectors. To avoid emissions of unburnt methane and the associated severe greenhouse effect of lean-burn engines, the stability of methane oxidation catalysts against steam-induced sintering at low temperatures $\left(<500^{\circ} \mathrm{C}\right.$ ) needs to be improved. Here we demonstrate how the combination of catalyst development and improved process control yields a highly efficient solution for complete methane oxidation. We design a material based on palladium and hierarchical zeolite with fully sodium-exchanged acid sites, which improves the support stability and prevents steam-induced palladium sintering under reaction conditions by confining the metal within the zeolite. Repeated short reducing pulses enable the use of a highly active transient state of the catalyst, which in combination with its high stability provides excellent performance without deactivation for over $90 \mathrm{~h}$ in the presence of steam.

\footnotetext{
${ }^{1}$ Paul Scherrer Institut (PSI), CH-5232 Villigen, Switzerland. ${ }^{2}$ ETH Zurich, Institute for Chemical and Bioengineering, $\mathrm{CH}-8093$ Zurich, Switzerland. ${ }^{3}$ École polytechnique fédérale de Lausanne (EPFL), Institute of Chemical Sciences and Engineering, CH-1015 Lausanne, Switzerland. Correspondence and requests for materials should be addressed to J.A.v.B.(email: jeroen.vanbokhoven@chem.ethz.ch) or to O.K. (email: oliver.kroecher@psi.ch)
} 
ncreasingly stringent emission regulations in the automotive sector force transition to cleaner fuels and more efficient combustion processes. Lean-burn natural gas vehicles are a promising mid-term alternative to gasoline and diesel vehicles due to the higher mass energy density of methane and lower carbon dioxide and $\mathrm{NO}_{\mathrm{x}}$ emissions ${ }^{1-5}$. However, lean-burn operation of a natural gas engine results in incomplete combustion of methane, the major component of natural gas. The 20 times larger global warming potential than carbon dioxide makes the control of methane emissions compulsory ${ }^{6-9}$. For this purpose, catalytic exhaust gas aftertreatment is used, which is currently based on conventional materials like $\mathrm{Pd} / \mathrm{Al}_{2} \mathrm{O}_{3}$ and its modification by ceria, $\mathrm{Pd} / \mathrm{SiO}_{2}, \mathrm{Pd} / \mathrm{ZrO}_{2}$, and $\mathrm{Pd} / \mathrm{SnO}_{2}{ }^{10-12}$. However, such systems have invariably poor hydrothermal stability, especially under realistic steady state operation at low temperature where steam-induced palladium sintering represents the major reason for deactivation ${ }^{13-15}$. Yet very few papers address this issue, preferring to focus on achieving the lowest possible light-off temperature in dry conditions and neglecting the problem of the steam-induced sintering ${ }^{1,16,17}$, although practical applications always involve the presence of large amounts of steam. Developing materials, which remain highly active during exposure to severe conditions with high steam concentration is essential to implement the use of natural gaspowered vehicles and power generation systems ${ }^{15,18,19}$.

Palladium supported on zeolite is a highly active material for complete methane oxidation ${ }^{2,15,20,21}$. Zeolites offer several advantages compared to metal oxide supports, the most fascinating one being the possibility to constrain small metal particles to protect them from sintering 22,23 , which is otherwise achieved upon laborious chemical treatment ${ }^{1,10,11}$. This opportunity has not been exploited so far for this reaction using zeolites. Lowsilica zeolites containing sodium were found to be active but showed poor stability under reaction conditions in the presence of steam ${ }^{20,21}$. High silicon to aluminum (Si/Al) ratios in Pd/ZSM5 and $\mathrm{Pd} /$ beta are beneficial for the activity and stability due to higher hydrophobicity and stability of the zeolite support ${ }^{24-27}$. However, achieving high dispersion of palladium within high silica zeolites is challenging due to their high hydrophobicity and small ion-exchange capacity, which do not allow incorporation of palladium into the zeolite pores. On the contrary, high dispersion even at high loadings of the active phase can be achieved at low $\mathrm{Si} / \mathrm{Al}$ ratios $^{26}$. While being advantageous for the synthesis in oxidizing conditions, the increased acidity of the zeolite could enhance the mobility of palladium over the support under reaction conditions, which include methane and large amounts of steam in the feed, eventually resulting in particle growth ${ }^{13}$. In addition, dealumination degrades the zeolite crystallinity and leads to the formation of acidic extra-framework aluminum species, which further promote palladium sintering ${ }^{13,28}$. Provided that the active palladium phase can be kept stable at high dispersion, the use of low-silica zeolite thus provides a unique opportunity to achieve high loading and high dispersion of the metal.

In this work, we design a highly active catalyst resistant to steam-induced sintering under reaction conditions by alleviating the origins of catalyst deactivation: high mobility of palladium nanoparticles and zeolite degradation. Both issues are solved by the synthetic approach based on the complete removal of the acid sites of the zeolite by post-exchange with sodium with simultaneous confinement of palladium nanoparticles within the zeolite. Additionally, with the help of operando X-ray absorption spectroscopy (XAS) revealing the beneficial redox properties of the catalyst, i.e., rapid palladium reduction and slow reoxidation, a new operation protocol is proposed, which maximizes the presence of a highly active transient state and provides stable conversion of methane for over $90 \mathrm{~h}$ in hydrothermal conditions with a negligible increase in methane emission.

\section{Results and Discussion}

Control of acidity by titration with sodium. The $\mathrm{Pd} / \mathrm{H}-\mathrm{MOR}$ catalyst was prepared by ion-exchange of $\mathrm{H}$-mordenite with tetraammine palladium nitrate followed by calcination in air at $500^{\circ}$ C. Fully sodium-exchanged $\mathrm{Pd} / \mathrm{Na}-\mathrm{MOR}$ was obtained by titrating the residual acid sites of $\mathrm{Pd} / \mathrm{H}-\mathrm{MOR}$ with a $0.01 \mathrm{M}$ solution of sodium bicarbonate. $\mathrm{Pd} / \mathrm{H}-\mathrm{MOR}$ and a reference $1 \mathrm{wt} \% \mathrm{Pd} / \mathrm{Al}_{2} \mathrm{O}_{3}$ catalyst prepared by wet impregnation showed similar light-offs in lean-burn methane oxidation, both providing $50 \%$ methane conversion $\left(T_{50}\right.$, Fig. 1a, Table 1$)$ at $400{ }^{\circ} \mathrm{C}$ and $435^{\circ} \mathrm{C}$, in the absence and presence of water vapor, respectively. The corresponding $T_{50}$ values of $\mathrm{Pd} / \mathrm{Na}-\mathrm{MOR}$ shifted considerably to 340 and $375^{\circ} \mathrm{C}$, and its intrinsic activity was identical to the most active palladium-based catalyst reported in literature (Supplementary Fig. 1) ${ }^{1}$. To cross-check the possible influence of acidity removal on deactivation of the system and exclude any other factor, such as change in the pore structure and crystallinity of the support material, $\mathrm{Pd} / \mathrm{Na}-\mathrm{MOR}$ was back-exchanged with ammonium nitrate and calcined to obtain the acidic $\mathrm{Pd} / \mathrm{H}-\mathrm{MOR}-$ BE. The $T_{50}$ values of this catalyst $\left(400 / 440^{\circ} \mathrm{C}\right)$ were close to the $T_{50}$ values of $\mathrm{Pd} / \mathrm{H}-\mathrm{MOR}$.

Despite the clear water poisoning effect over all catalysts (Fig. 1a), the enhanced activity of Pd/Na-MOR was accompanied by a significant increase in stability (Fig. 1b). The acidic catalysts, $\mathrm{Pd} / \mathrm{H}-\mathrm{MOR}$ and $\mathrm{Pd} / \mathrm{H}-\mathrm{MOR}-\mathrm{BE}$, as well as $\mathrm{Pd} / \mathrm{Al}_{2} \mathrm{O}_{3}$, exhibited rapid deactivation within the first $4 \mathrm{~h}$ on stream, in agreement with observations by others ${ }^{14,15,20}$. On the contrary, methane conversion over $\mathrm{Pd} / \mathrm{Na}-\mathrm{MOR}$ improved and the initial 35\% difference in conversion increased to $65 \%$ after $4 \mathrm{~h}$. Negligible variations in crystallinity (X-ray diffraction, XRD; Supplementary Fig. 2, Supplementary Table 1), pore structure and surface area (argon physisorption, Supplementary Fig. 3, Supplementary Table 2), and aluminum coordination $\left({ }^{27} \mathrm{Al}\right.$ MAS NMR, Supplementary Fig. 4) in the three catalysts suggest that addition and removal of sodium to $\mathrm{Pd} / \mathrm{H}-\mathrm{MOR}$ did not affect the structure of the zeolite, but changed its acidity. This was also inferred from ammonia desorption profiles (Table 1, Supplementary Fig. 5, Supplementary Table 3) and the vibrational fingerprints of ammonia adsorption/desorption in infrared spectroscopy (Supplementary Fig. 6). The similarity between $\mathrm{Pd} / \mathrm{H}-\mathrm{MOR}$ and $\mathrm{Pd} /$ $\mathrm{H}-\mathrm{MOR}-\mathrm{BE}$ and the superior performance of fully exchanged $\mathrm{Pd} /$ Na-MOR suggest that the acidity of the zeolite controls the catalytic behavior of the system. This was further confirmed by the extensive study of the effect of sodium loading on the activity of Pd/MOR (Supplementary Table 4), which showed that the optimal amount of sodium corresponded to the fully exchanged acid sites of the zeolite. Addition of insufficient amounts of sodium did not significantly improve the performance of $\mathrm{Pd} /$ MOR, whereas an excess of sodium caused rapid deactivation of the catalyst. Despite the possible influence of sodium on kinetics and on the reaction mechanism ${ }^{29}$, no significant difference in reaction orders and activation energy was observed between $\mathrm{Pd}$ / $\mathrm{H}-\mathrm{MOR}$ and $\mathrm{Pd} / \mathrm{Na}-\mathrm{MOR}$ (Table 2). Hence, some other factor is responsible for the improved performance of $\mathrm{Pd} / \mathrm{Na}-\mathrm{MOR}$.

The scanning transmission electron microscopy (STEM) images of $\mathrm{Pd} / \mathrm{H}-\mathrm{MOR}$ (Fig. 2a) exhibited homogeneously distributed palladium nanoparticles with a mean diameter of $1.3 \mathrm{~nm}$ (Supplementary Fig. 7). Removal of acidity by sodium exchange (Fig. 2c) resulted in a moderate aggregation of palladium and the mean diameter of the metal particles of $\mathrm{Pd} /$ $\mathrm{Na}-\mathrm{MOR}$ increased to $3.0 \mathrm{~nm}$. The decrease of the mean particle size to $2.4 \mathrm{~nm}$ after removal of sodium (Pd/H-MOR-BE) 

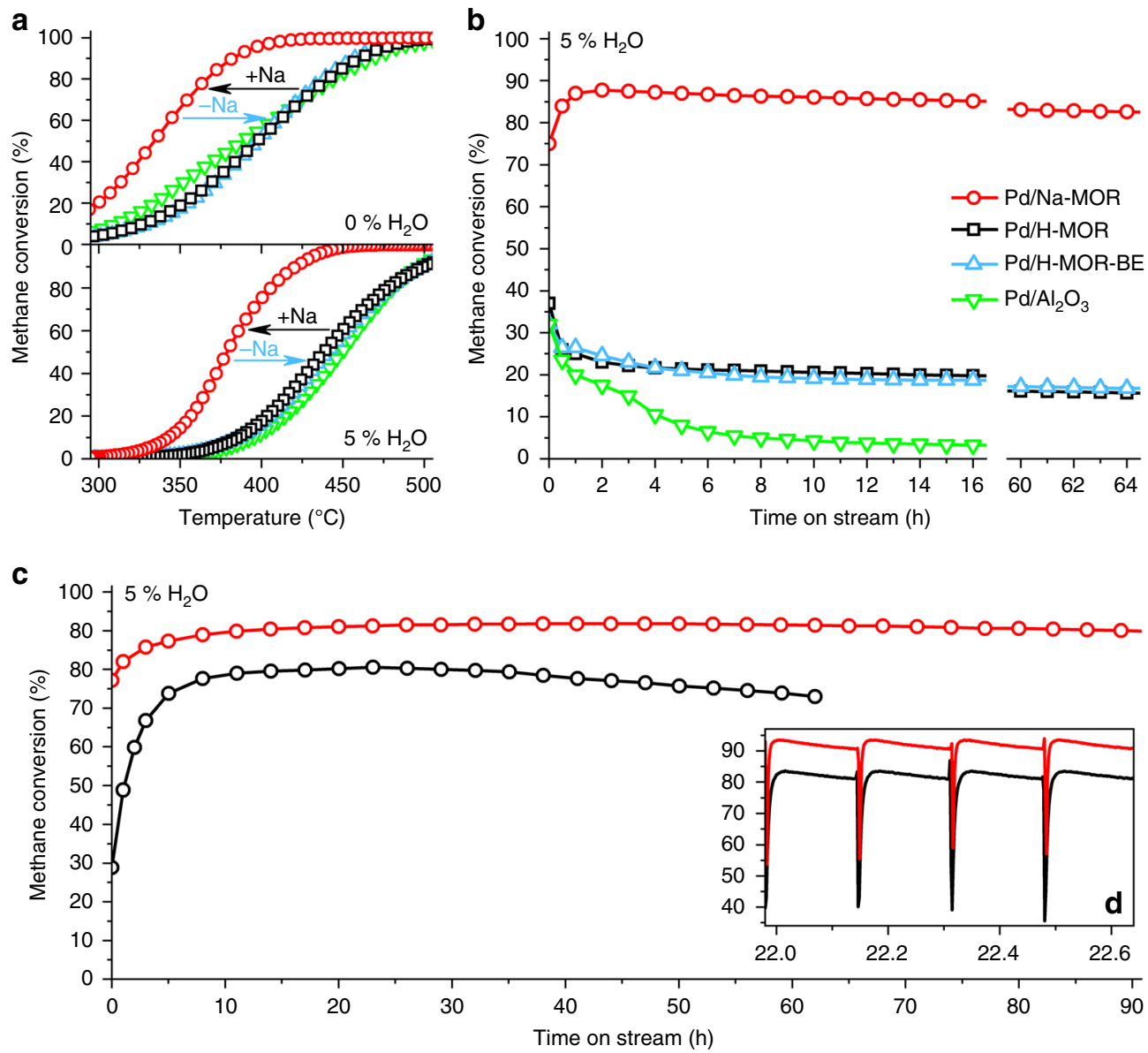

Fig. 1 Catalytic activity of $\mathrm{Pd} / \mathrm{Al}_{2} \mathrm{O}_{3}$ and various $\mathrm{Pd} /$ mordenite catalysts. a Light-off curves, $\mathbf{b} 65 \mathrm{~h}$ stability test without regeneration, and $\mathbf{c}$ stability test with continuous short pulse regeneration (averaged values including methane slip during regeneration). Conditions: 1 vol\% $\mathrm{CH}_{4}, 4$ vol\% $\mathrm{O}_{2}, \mathrm{O}$ or 5 vol\% $\mathrm{H}_{2} \mathrm{O}$, bal. $\mathrm{N}_{2}$; gas hourly space velocity $(\mathrm{GHSV})=70,000 \mathrm{~h}^{-1} ; \mathrm{T}=415^{\circ} \mathrm{C}$ for stability tests; lean operation: 10 min; regeneration (short rich operation): $3 \mathrm{~s}$; d magnification of four cycles with regeneration over Pd/H-MOR and Pd/Na-MOR. Prior to the tests, the catalysts were degreened at $550{ }^{\circ} \mathrm{C}$ for 30 min in 1 vol\% $\mathrm{CH}_{4}, 4$ vol\% $\mathrm{O}_{2}, 95$ vol\% $\mathrm{N}_{2}$

Table 1 Physico-chemical properties of Pd/MOR catalysts

\begin{tabular}{|c|c|c|c|c|c|c|}
\hline Sample & Si/Al ratio ${ }^{a}$ & $\mathrm{Na}^{\mathrm{a}}, \mathbf{w t} \%$ & $\mathrm{Pd}^{\mathrm{a}}, \mathrm{wt} \%$ & $\begin{array}{l}\text { Surface areab, } \mathrm{m}^{2} / \mathrm{g} \\
\text { (calcined/spent } 16 \mathrm{~h} \text { ) }\end{array}$ & $\begin{array}{l}\text { Crystallinityc, } \\
\% \text { (spent } 16 \text { h) }\end{array}$ & $\begin{array}{l}\text { Strong acid } \\
\text { sites }^{d}, \text { mmol/g }\end{array}$ \\
\hline $\mathrm{Pd} / \mathrm{H}-\mathrm{MOR}$ & 17.2 & 0.06 & 1.01 & $418 / 414$ & 93 & 0.62 \\
\hline $\mathrm{Pd} / \mathrm{Na}-\mathrm{MOR}$ & 17.2 & 1.43 & 0.99 & $400 / 402$ & 93 & 0.10 \\
\hline $\mathrm{Pd} / \mathrm{H}-\mathrm{MOR}-\mathrm{BE}$ & 17.2 & 0.01 & 0.98 & $416 / 415$ & 91 & 0.54 \\
\hline
\end{tabular}

Table 2 Kinetic analysis of Pd/H-MOR and Pd/Na-MOR

\begin{tabular}{|c|c|c|c|c|c|}
\hline Sample & $\begin{array}{l}\text { Reaction orders }\left(\mathrm{CH}_{4} / \mathrm{O}_{2} /\right. \\
\left.\mathrm{H}_{2} \mathrm{O}\right)\end{array}$ & $\begin{array}{l}E_{\text {act, }}, \mathbf{k J} / \mathrm{mol}(0 / 5 \mathrm{vol} \\
\left.\% \mathrm{H}_{2} \mathrm{O}\right)\end{array}$ & $\begin{array}{l}T_{50},{ }^{\circ} \mathrm{C}(0 / 5 \mathrm{vol} \\
\left.\% \mathrm{H}_{2} \mathrm{O}\right)\end{array}$ & $\begin{array}{l}\text { TOF }^{\mathrm{a}}, \mathrm{s}^{-1}\left(275^{\circ} \mathrm{C},\right. \\
\left.0 \% \mathrm{H}_{2} \mathrm{O}\right)\end{array}$ & $\begin{array}{l}\operatorname{TOF}^{\mathrm{a}}, \mathrm{s}^{-1}\left(340{ }^{\circ} \mathrm{C},\right. \\
\left.5 \% \mathrm{H}_{2} \mathrm{O}\right)\end{array}$ \\
\hline $\mathrm{Pd} / \mathrm{H}-\mathrm{MOR}$ & $0.9 / 0.1 /-1.0$ & $84 / 155$ & $395 / 435$ & 0.003 & 0.002 \\
\hline $\mathrm{Pd} / \mathrm{Na}-\mathrm{MOR}$ & $1.0 / 0.1 /-1.1$ & $75 / 158$ & $335 / 375$ & 0.013 & 0.014 \\
\hline
\end{tabular}



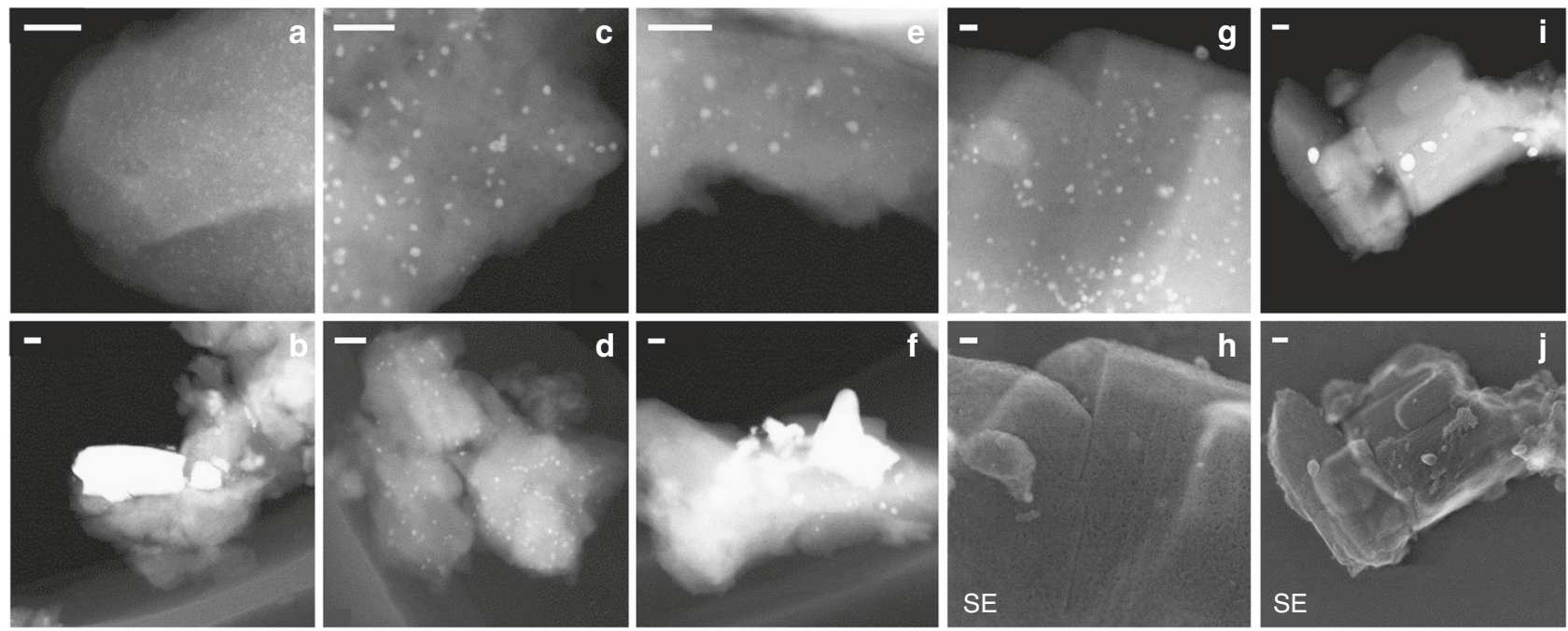

Fig. 2 Representative electron microscopy images of calcined and spent catalysts. a, b Pd/H-MOR, c, d Pd/Na-MOR, e, f Pd/H-MOR-BE. Spent catalysts were aged in 1 vol\% $\mathrm{CH}_{4}, 4$ vol\% $\mathrm{O}_{2}, 5$ vol\% $\mathrm{H}_{2} \mathrm{O}, \mathrm{N}_{2}$ bal. at $415^{\circ} \mathrm{C}$ for $16 \mathrm{~h}$. STEM and secondary electron (SE) images of $\mathbf{g}$, $\mathbf{h ~ P d / N a - M O R}$ and $\mathbf{i}, \mathbf{j} \mathrm{Pd} / \mathrm{H}-$ MOR after $90 \mathrm{~h}$ and $65 \mathrm{~h}$ on stream, respectively, continuous with short pulse regeneration. Scale bar: $20 \mathrm{~nm}(\mathbf{a}-\mathbf{h})$ and $50 \mathrm{~nm}(\mathbf{i}, \mathbf{j})$
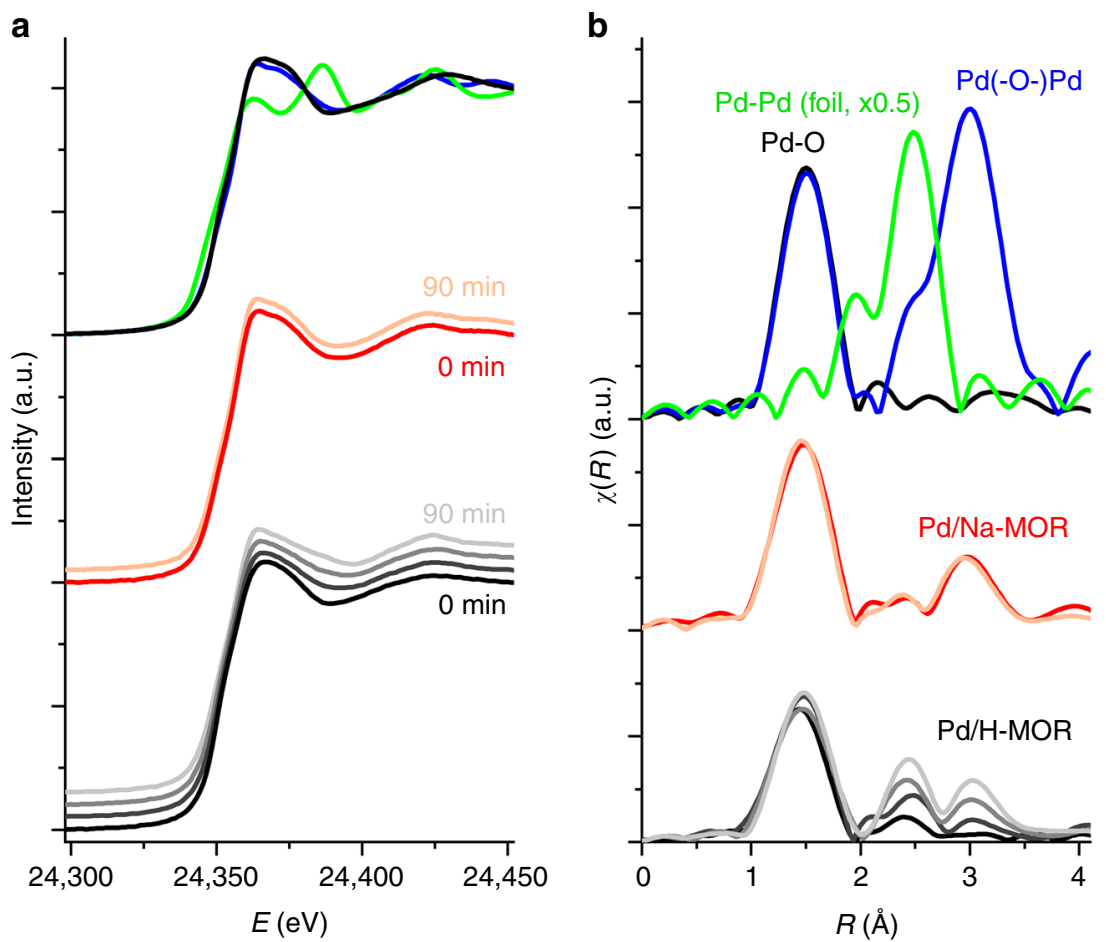

Fig. 3 In situ X-ray absorption spectroscopy of catalyst aging. a X-ray absorption near-edge structure (XANES) spectra and $\mathbf{b}$ the corresponding Fourier transforms of in situ Pd K-edge extended X-ray absorption fine structure (EXAFS) spectra (non-phase shift corrected) of the catalysts after pretreatment (10 min in 1 vol\% $\mathrm{CH}_{4}, 4$ vol\% $\mathrm{O}_{2}$, bal. $\mathrm{N}_{2}, \mathrm{GHSV}=350,000 \mathrm{~h}^{-1}$ at $410{ }^{\circ} \mathrm{C}$ ) and after 15, 30, and 90 min aging in a feed of 1 vol\% $\mathrm{CH}_{4}, 4 \mathrm{vol} \% \mathrm{O}_{2}, 5$ vol\% $\mathrm{H}_{2} \mathrm{O}$, bal. $\mathrm{N}_{2}$ at $410^{\circ} \mathrm{C}: \mathrm{Pd} / \mathrm{H}-\mathrm{MOR}$ (black to light gray); $\mathrm{Pd} / \mathrm{Na}-\mathrm{MOR}$ (red to pink); bulk PdO (blue); calcined Pd/H-MOR (black); and palladium foil (green). The spectra and Fourier transforms are offset for clarity

evidenced the partial redispersion of palladium, accompanied by restoration of the support acidity (Supplementary Fig. 5). Figure 2e shows two distinct particle sizes in Pd/H-MOR-BE: the smaller particles $(1-1.5 \mathrm{~nm})$ similar to those in the parent $\mathrm{Pd} /$ $\mathrm{H}-\mathrm{MOR}$ and the larger ones $(2-4 \mathrm{~nm})$ like in $\mathrm{Pd} / \mathrm{Na}-\mathrm{MOR}$. This aggregation-redispersion phenomenon was also confirmed by analysis of the ex situ Pd K-edge extended X-ray absorption fine structure (EXAFS) spectra (Supplementary Fig. 8) and agrees with the previous observations on $\mathrm{Pd} / \mathrm{H}$-zeolite and $\mathrm{Pd} / \mathrm{Na}$-zeolite ${ }^{30}$, where palladium tended to stay more aggregated on the sodiumexchanged zeolite. Such behavior suggests that palladium can actively interact with the acid sites of the zeolite, which can promote mobility of the metal over the support in the presence of water vapor under reaction conditions ${ }^{13}$. STEM micrographs of the catalysts exposed to reaction conditions for $16 \mathrm{~h}$ revealed sintering of the active phase in $\mathrm{Pd} / \mathrm{H}-\mathrm{MOR}$ and $\mathrm{Pd} / \mathrm{H}-\mathrm{MOR}-\mathrm{BE}$ (Fig. 1b,f) with highly inhomogeneous particle size ranging from 3 to $50 \mathrm{~nm}$ (Supplementary Fig. 7) and the average nanoparticle 
size was $14 \mathrm{~nm}$ and $11 \mathrm{~nm}$, respectively. On the contrary, no significant change in palladium dispersion occurred in $\mathrm{Pd} / \mathrm{Na}$ MOR (an average of $3.0 \mathrm{~nm}$ for the calcined material, and $4.4 \mathrm{~nm}$ and $4.6 \mathrm{~nm}$ for samples spent for $16 \mathrm{~h}$ and $65 \mathrm{~h}$, respectively).

The micrographs of Pd/Na-MOR (Fig. 2c, d) exhibited a large fraction of palladium nanoparticles within the dark areas of the zeolite crystallites, which are typically recognized as mesopores ${ }^{31}$. The location of these particles was confirmed to be the zeolite interior by STEM with simultaneous secondary electron detection (Fig. 2g, h), whereas only a few particles were detected on the external surface of the zeolite. The native $\mathrm{H}$-mordenite with a Si/ $\mathrm{Al}$ ratio of 17 used in this study was dealuminated by the supplier and it is well-known that dealumination of zeolites produces mesopores ${ }^{32-36}$. Exchange of sodium likely caused aggregation of palladium within such cavities of the support, trapping the active phase in a well-dispersed form within the zeolite ${ }^{37}$. The acid sites, which caused internal exchange and mobility of palladium in the presence of water vapor, were removed in $\mathrm{Pd} / \mathrm{Na}-\mathrm{MOR}$, and this, thus ensured that palladium remained confined within the zeolite.

Redox properties and transient state. The increase in the intensities and narrowing of the peaks of palladium oxide reflections in the XRD patterns of the spent $\mathrm{Pd} / \mathrm{H}-\mathrm{MOR}$ and $\mathrm{Pd} /$ H-MOR-BE catalysts compared to the calcined ones (Supplementary Fig. 2) support the conclusions about the particle size drawn from STEM. Additionally, both palladium oxide and metallic palladium were detected in the spent acidic catalysts $(\mathrm{Pd} /$ $\mathrm{H}-\mathrm{MOR}$ and $\mathrm{Pd} / \mathrm{H}-\mathrm{MOR}-\mathrm{BE}$ ), whereas only palladium oxide was present in fresh and spent $\mathrm{Pd} / \mathrm{Na}-\mathrm{MOR}$. To further study the observed difference in the oxidation state of palladium and elucidate the possible influence of sodium, $\mathrm{Pd} / \mathrm{H}-\mathrm{MOR}$ and $\mathrm{Pd} / \mathrm{Na}-$ MOR were exposed to the reaction conditions at $400{ }^{\circ} \mathrm{C}$ for 90 min while measuring in situ Pd K-edge EXAFS. The Fourier transforms (FT) of the spectra obtained at selected time intervals (Fig. 3, Table 3) show a gradual increase in the Pd-Pd (peak in FT at $2.5 \AA$, non-phase shift corrected) and $\mathrm{Pd}(-\mathrm{O}-) \mathrm{Pd}$ (peak in FT at $3.0 \AA$, non-phase shift corrected) coordination shells of $\mathrm{Pd} / \mathrm{H}$ MOR over time ${ }^{26}$. The fractions of oxidized and reduced palladium were determined from the fractional coordination numbers. Assuming that the coordination number of $\mathrm{Pd}-\mathrm{O}\left(\mathrm{CN}_{\mathrm{Pd}-\mathrm{O}}\right)$ is 4 ( $\mathrm{CN}$ fitting error here and below is \pm 0.6 ), the value of $\mathrm{CN}_{\mathrm{Pd}-\mathrm{O}} \approx 3$ in $\mathrm{Pd} / \mathrm{H}-\mathrm{MOR}$ corresponded to about $75 \%$ of oxidic palladium. The coordination number of fully coordinated metallic palladium $\left(\mathrm{CN}_{\mathrm{Pd}-\mathrm{Pd}}\right)$ at this reduction level would be 3 and therefore the value of $2.8 \mathrm{in} \mathrm{Pd} / \mathrm{H}-\mathrm{MOR}$ aged for $90 \mathrm{~min}$ indicates that reduced palladium was organized in large particles with an average coordination number of about 11. In contrast, no significant difference in the state of palladium was observed in $\mathrm{Pd} / \mathrm{Na}-\mathrm{MOR}$ after $90 \mathrm{~min}$ suggesting that it always remained fully oxidized $\left(\mathrm{CN}_{\mathrm{Pd}-\mathrm{O}} \approx 4\right)$.

Subsequent to the steady state operation $\left(90 \mathrm{~min}\right.$ at $400^{\circ} \mathrm{C}$ ), we assessed the redox properties of palladium in the absence and presence of sodium in a transient time-resolved XAS experiment (Fig. 4). Oxygen was removed from the feed to reduce the catalyst by methane and then added again to allow palladium reoxidation under reaction conditions. The results of the XANES linear combination fit, illustrated in Fig. 4a, show that after removal of oxygen the initially fully oxidized aged $\mathrm{Pd} / \mathrm{Na}-\mathrm{MOR}$ was completely reduced within the first few seconds. In the reduction period, both catalysts continued to convert methane to carbon dioxide and hydrogen by steam reforming. When oxygen was reintroduced, the catalyst slowly reoxidized and contained $95 \%$ of $\mathrm{Pd}^{2+}$ after 5 min of reoxidation. Similarly, the complete reduction of initially partly reduced aged $\mathrm{Pd} / \mathrm{H}-\mathrm{MOR}\left(62 \%\right.$ of $\left.\mathrm{Pd}^{2+}\right)$ occurred upon the removal of oxygen, followed by the slow

\section{Table 3 Coordination numbers obtained from fitting the EXAFS spectra}

\begin{tabular}{|c|c|c|c|c|c|}
\hline Experiment & $\mathrm{CN}_{\mathrm{Pd}-\mathrm{O}}{ }^{\mathrm{a}}$ & $\mathbf{C N}_{\mathbf{P d}-\mathbf{P d}}$ & $\begin{array}{l}C_{\text {Pd }}{ }_{\text {(-O-)Pd }} \\
\text { b }\end{array}$ & $\begin{array}{l}\text { Fract. } \\
\text { CN }_{\text {Pd-Pd }}{ }^{c}\end{array}$ & $\begin{array}{l}\text { Fract. CN } \\
\text { (-O-)Pd }\end{array}$ \\
\hline \multicolumn{6}{|l|}{ Ex situ, $20^{\circ} \mathrm{C}$} \\
\hline $\mathrm{PdO}$ & 4 & - & 12 & - & 12 \\
\hline Pd foil & - & 12 & & 12 & - \\
\hline $\mathrm{Pd} / \mathrm{H}-\mathrm{MOR}$ & 4 & - & - & - & - \\
\hline $\mathrm{Pd} / \mathrm{Na}-\mathrm{MOR}$ & 4 & - & 6 & - & 6 \\
\hline $\mathrm{Pd} / \mathrm{H}-\mathrm{MOR}-\mathrm{BE}$ & 4 & - & 3.3 & - & 3.3 \\
\hline \multicolumn{6}{|c|}{ Aging at $400^{\circ} \mathrm{C}$ (Fig. 3) } \\
\hline \multicolumn{6}{|c|}{$\mathrm{Pd} / \mathrm{H}-\mathrm{MOR}$} \\
\hline $0 \mathrm{~min}$ & 2.9 & 0.5 & 1.0 & 1.8 & 1.4 \\
\hline $15 \mathrm{~min}$ & 2.9 & 1.6 & 2.7 & 5.8 & 3.7 \\
\hline $30 \mathrm{~min}$ & 2.9 & 1.9 & 4.2 & 6.9 & 5.8 \\
\hline $90 \mathrm{~min}$ & 3 & 2.8 & 7.0 & 11.2 & 9.3 \\
\hline \multicolumn{6}{|l|}{$\mathrm{Pd} / \mathrm{Na}-\mathrm{MOR}$} \\
\hline $0 \mathrm{~min}$ & 3.9 & - & 6.0 & - & 6.2 \\
\hline $90 \mathrm{~min}$ & 3.9 & - & 6.6 & - & 6.8 \\
\hline \multicolumn{6}{|c|}{ Redox at $350^{\circ} \mathrm{C}$ (Fig. 4) } \\
\hline \multicolumn{6}{|c|}{$\mathrm{Pd} / \mathrm{H}-\mathrm{MOR}$} \\
\hline $1 \mathrm{~s}$ & 2.4 & 4.6 & 5.2 & 11.5 & 8.7 \\
\hline $90 \mathrm{~s}$ & - & 11.3 & - & 11.3 & - \\
\hline $210 s$ & - & 11.3 & - & 11.3 & - \\
\hline $280 \mathrm{~s}$ & 1.4 & 7.0 & 3.9 & 10.8 & 11.1 \\
\hline $550 \mathrm{~s}$ & 2.3 & 4.9 & 6.3 & 11.5 & 11.0 \\
\hline \multicolumn{6}{|l|}{$\mathrm{Pd} / \mathrm{Na}-\mathrm{MOR}$} \\
\hline $1 \mathrm{~s}$ & 3.9 & - & 6.7 & - & 6.9 \\
\hline $90 \mathrm{~s}$ & - & 10.2 & - & 10.2 & - \\
\hline $210 s$ & - & 10.4 & - & 10.4 & - \\
\hline $280 \mathrm{~s}$ & 2.4 & 3.6 & 2.3 & 9.0 & 3.8 \\
\hline $550 \mathrm{~s}$ & 3.6 & 1.2 & 6.9 & 12.0 & 7.7 \\
\hline \multicolumn{6}{|c|}{$\begin{array}{l}\text { a The absolute error value of the fitted coordination numbers is in the order of } \pm 0.6 \\
\text { b The } \mathrm{Pd}(-\mathrm{O}-\mathrm{Pd} \text { shell is a sum of two scattering paths with the maximum coordination } \\
\text { numbers of } 4 \text { and } 8 \\
\text { c The fractional coordination numbers are obtained from normalization by the fraction of } \\
\text { reduced/oxidized palladium from } \mathrm{CN}_{\mathrm{Pd}-\mathrm{O}}\end{array}$} \\
\hline
\end{tabular}

reoxidation under reaction conditions. After $5 \mathrm{~min}, \mathrm{Pd} / \mathrm{H}-\mathrm{MOR}$ had a slightly lower fraction of $\mathrm{Pd}^{2+}(58 \%)$ than before reduction. Despite the similar behavior of $\mathrm{Pd} / \mathrm{H}-\mathrm{MOR}$ and $\mathrm{Pd} / \mathrm{Na}-\mathrm{MOR}$ during reduction and reoxidation, the steady state fraction of $\mathrm{Pd}^{2}$ + under reaction conditions was significantly higher in $\mathrm{Pd} / \mathrm{Na}$ MOR. We attribute this behavior to about four times faster reoxidation rate of $\mathrm{Pd}^{0}$ to $\mathrm{Pd}^{2+}$ in the presence of sodium (the initial rates are shown in Fig. 4), considering that smaller metal nanoparticles with larger specific surface area are generally more reactive towards oxygen ${ }^{38,39}$, and that the palladium particle size was smaller in $\mathrm{Pd} / \mathrm{Na}-\mathrm{MOR}$ as inferred from the $\mathrm{CN}_{\mathrm{Pd}-\mathrm{Pd}}$ of the fully reduced catalysts (90 and $210 \mathrm{~s}$; Table 3, Supplementary Figs. 9 and 10).

After oxygen was re-introduced, methane conversion over $\mathrm{Pd} /$ $\mathrm{H}-\mathrm{MOR}$ and $\mathrm{Pd} / \mathrm{Na}-\mathrm{MOR}$ increased transiently to $78 \%$ and $86 \%$, respectively, and then stabilized at a higher steady state activity level than before reduction. The increased activity upon reoxidation of reduced palladium can be attributed either to the formation of a highly dispersed $\mathrm{PdO}$ phase (redispersion), to the increased surface roughness of freshly reoxidized $\mathrm{PdO}$, or to the presence of the interface between the reduced and oxidized palladium ${ }^{40}$. The coordination numbers of palladium in $\mathrm{Pd} / \mathrm{Na}$ MOR (Table 3) showed that under reducing conditions (210 s) palladium existed as large reduced particles, which quickly partially reoxidized as soon as oxygen was added to the feed (280 s). Peculiarly, the $\mathrm{Pd}(-\mathrm{O}-) \mathrm{Pd}$ shell of palladium in $\mathrm{Pd} / \mathrm{Na}$ MOR was almost undetectable in this transient state, which 
a
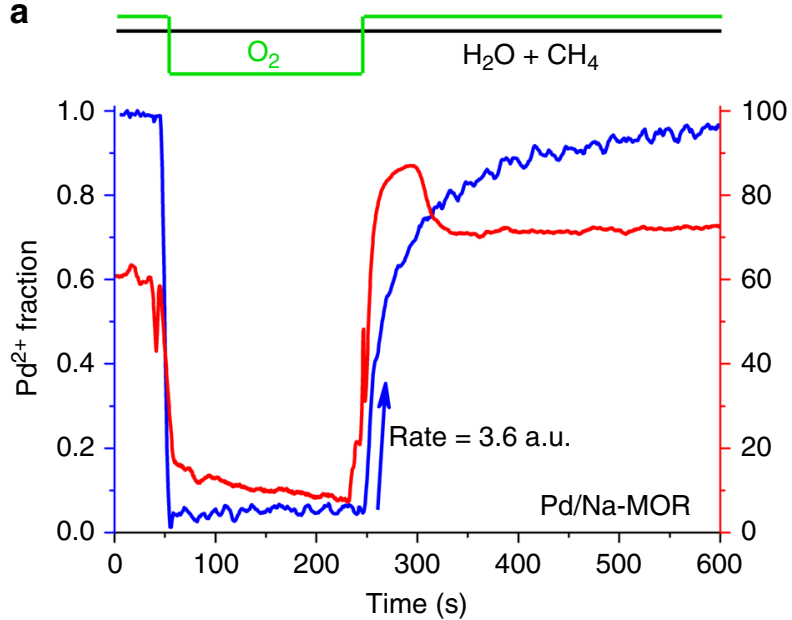

b 1.0

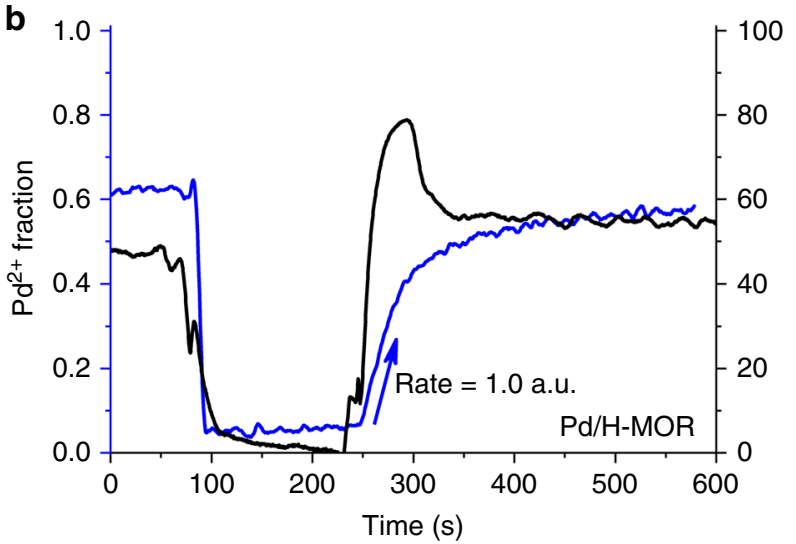

C

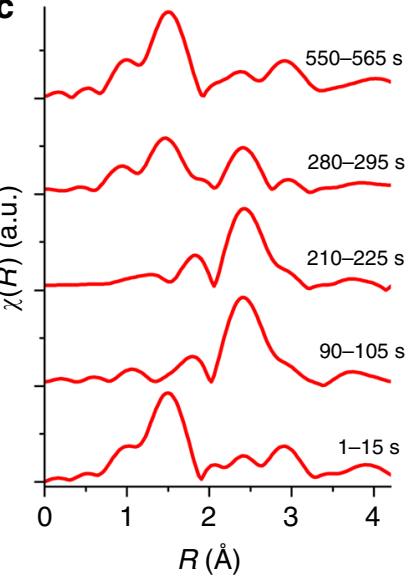

d

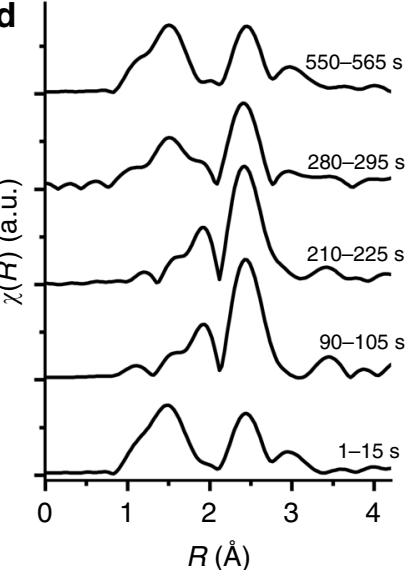

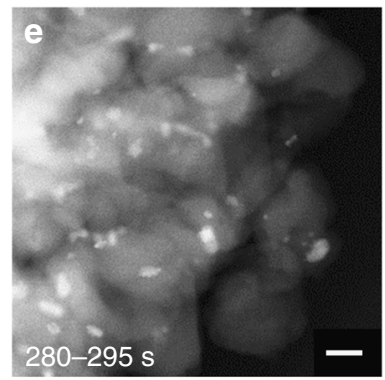

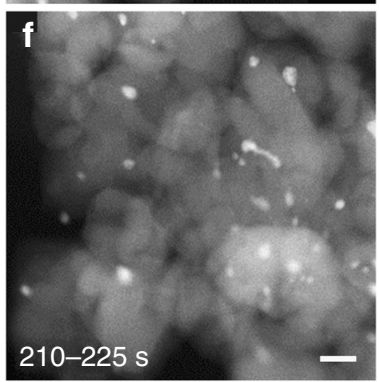

g

Fig. 4 Transient operando EXAFS experiment with oxygen cut-off. a, b Fraction of oxidized palladium in Pd/Na-MOR and Pd/H-MOR and corresponding catalytic activity in 1 vol\% $\mathrm{CH}_{4}, 4$ vol\% $\mathrm{O}_{2}, 5$ vol\% $\mathrm{H}_{2} \mathrm{O}$, bal. $\mathrm{N}_{2}, \mathrm{GHSV}=350,000 \mathrm{~h}^{-1}$ at $350^{\circ} \mathrm{C}$. Oxygen was removed from the feed to perform reduction of palladium by methane and then added for subsequent reoxidation in reaction conditions. c, d Fourier transforms of in situ Pd K-edge EXAFS spectra (non-phase shift corrected) of Pd/Na-MOR and Pd/H-MOR upon averaging 15 spectra at 1, 90, 210, 280, and 550 s of the experiment. Corresponding coordination numbers are given in Table 2 . Initial rates were obtained from fitting the linear function over the first 10 points during reoxidation. $\mathbf{e}, \mathbf{f}, \mathbf{g}$ STEM images of the quenched Pd/H-MOR at 1, 210, and 280 s. Scale bar: $20 \mathrm{~nm}$

implies that palladium oxide existed as very small entities. STEM analysis (Fig. 4e-g, Supplementary Figs. 11 and 12) confirmed that no redispersion of palladium occurred and the particles exhibited irregular morphology both before and after the reducing pulse, suggesting that the difference in the particle shape is unlikely the reason for the high transient activity. According to some previous work, the PdO-Pd interface is unlikely to provide enhanced methane oxidation activity due to the strongly chemisorbed oxide layer on metallic palladium ${ }^{41,42}$, and therefore the high activity in the transient state may occur due to the increased amount of oxygen vacancies ${ }^{43,44}$ in freshly reoxidized palladium caused by volume change and surface roughening ${ }^{0,45}$. The extinction of the transient state was followed by a slower reoxidation rate of palladium, suggesting that the surface of palladium fully reoxidized and further oxidation was suppressed by the oxygen diffusion to the bulk of palladium particles. The system reached a new steady state, in which $\mathrm{Pd} / \mathrm{H}-\mathrm{MOR}$ and $\mathrm{Pd} / \mathrm{Na}-\mathrm{MOR}$ showed $8 \%$ and $15 \%$ higher methane conversion than before reduction (1 s), respectively. The incomplete reoxidation of $\mathrm{Pd} / \mathrm{H}-\mathrm{MOR}$ operated under the steady state can be explained by the above described phenomenon of fast surface and slow bulk reoxidation of its large particles, which likely produced bulk metal particles coated by an oxide shell ${ }^{46}$. Interestingly, the effect of redox pulsing on $\mathrm{Pd} / \mathrm{H}-\mathrm{MOR}$ with large particles was much more pronounced compared to highly dispersed $\mathrm{Pd} / \mathrm{Na}-\mathrm{MOR}$, suggesting that the activity of the transient state does not correlate with palladium particle size. Such effect is not surprising, since activity of the catalyst in the active transient state is defined by the surface roughness and the amount of oxygen vacancies in the freshly reoxidized PdO.

Practical implications. The enhanced conversion in the transient state can be exploited for practical use to prevent the long-term deactivation. While reducing treatments are known to regenerate poisoned catalysts after steady-state operation ${ }^{47}$, the rapid reduction of palladium in the absence of oxygen in the feed demonstrated in this work allows to decrease the reduction time to a few seconds. Thus, instead of the conventional steady state operation, the catalyst can be continuously operated in the highly active transient state provoked by short reducing pulses applied between longer lean periods without a significant increase in methane emissions associated with such reduction. Figure 1c shows the stability of $\mathrm{Pd} / \mathrm{H}-\mathrm{MOR}$ and $\mathrm{Pd} / \mathrm{Na}-\mathrm{MOR}$ during operation with continuous short pulses, wherein oxygen was removed from the feed for $3 \mathrm{~s}$ at the intervals of $10 \mathrm{~min}$. This operation mode initially increased the methane oxidation activity over Pd/Na-MOR and allowed to maintain the high conversion level of $90 \%$ without a significant change in activity of the catalyst for over $90 \mathrm{~h}$ on stream. This high conversion level is maintained, 
because of the continuous regeneration of the highly active transient state during the reduction/reoxidation cycles identified by operando XAS. Its lifetime in the stationary reactor (Fig. 1c) is longer than in the capillary used for the XAS measurements (Fig. 4a) due to the lower space velocity $\left(70,000 \mathrm{~h}^{-1}\right)$ compared to the spectroscopic experiment $\left(350,000 \mathrm{~h}^{-1}\right)$. On the contrary, $\mathrm{Pd} /$ H-MOR showed deactivation in the stability test, although the repeated short pulses increased the highest conversion of methane to $79 \%$ compared to $37 \%$ obtained in the conventional mode. Such difference occurred due to the superior sintering resistance of $\mathrm{Pd} / \mathrm{Na}-\mathrm{MOR}$ compared to $\mathrm{Pd} / \mathrm{H}-\mathrm{MOR}$ as evidenced by STEM (Fig. $2 \mathrm{~g}-\mathrm{j}$ ). The strategy described above can be readily implemented, since modern engines are designed for switching between lean, stoichiometric, and rich operation modes to optimize fuel consumption and to control exhaust gas aftertreatment devices, which is used in existing technologies for $\mathrm{NO}_{\mathrm{x}}$ abatement like three-way catalyst (TWC) and lean $\mathrm{NO}_{\mathrm{x}}$ trap (LNT).

This work shows that palladium can be efficiently stabilized at high dispersion within the mesopores of dealuminated hierarchical mordenite. The mobility of palladium was inhibited by fully exchanging the acid sites of the zeolite with sodium, which kept palladium highly dispersed and prevented steam-induced sintering under reaction conditions. Due to the very rapid reduction and the slow reoxidation of palladium observed by transient operando XAS, it was possible to maintain the catalyst at high transient activity compared to steady state conditions by applying very short reducing pulses of methane between longer lean periods. This sustained the highly active transient state, palladium oxide with increased amount of oxygen vacancies, providing higher steady state activity in methane oxidation and, in combination with the sintering-resistant $\mathrm{Pd} / \mathrm{Na}-\mathrm{MOR}$, stable methane conversion for over $90 \mathrm{~h}$ in hydrothermal conditions.

\section{Methods}

Materials and synthesis. Commercial dealuminated mordenite was supplied by Zeochem $\left(\mathrm{FM}-8 / 25 \mathrm{H}, \mathrm{Si} / \mathrm{Al}=17, \mathrm{H}^{+}\right.$form). The zeolite was ion-exchanged with the amount of tetraammine palladium nitrate solution $(\mathrm{pH}=7)$ corresponding to the nominal $1 \mathrm{wt} \%$ loading of palladium at room temperature for $24 \mathrm{~h}$. After drying at $120^{\circ} \mathrm{C}$ for $6 \mathrm{~h}$, the catalyst was calcined in air at $500^{\circ} \mathrm{C}$ for $2 \mathrm{~h}$ in a muffle oven. The heating ramp was set to $2^{\circ} \mathrm{C} \mathrm{min}-1$ to form highly dispersed palladium particles. The resulting material was denoted as $\mathrm{Pd} / \mathrm{H}-\mathrm{MOR}$.

A batch of $\mathrm{Pd} / \mathrm{H}-\mathrm{MOR}(25 \mathrm{~g})$ was dispersed in deionized water $(250 \mathrm{ml})$ and treated with a diluted solution of sodium bicarbonate $(0.01 \mathrm{M}, \mathrm{pH}=8)$, which was added dropwise to the slurry $(\mathrm{pH}=3.5)$ within $90 \mathrm{~min}$ until it was neutralized $(\mathrm{pH}$ $=7$ ). The slurry was then stirred for $30 \mathrm{~min}$, centrifuged to recover the solid, dried at $120^{\circ} \mathrm{C}$ for $6 \mathrm{~h}$, and calcined in air at $500^{\circ} \mathrm{C}$ for $2 \mathrm{~h}$. The obtained catalyst was labeled as $\mathrm{Pd} / \mathrm{Na}-\mathrm{MOR}$. The $\mathrm{Pd} / \mathrm{Na}-\mathrm{MOR}$ catalyst $(3 \mathrm{~g})$ was then ion-exchanged three times with ammonium nitrate $(1 \mathrm{M}, 100 \mathrm{ml}, 24 \mathrm{~h})$ to back-exchange the sodium followed by drying and calcination procedures as described above. The resulting catalyst was denoted as $\mathrm{Pd} / \mathrm{H}-\mathrm{MOR}-\mathrm{BE}$. Excessively exchanged $\mathrm{Pd} / \mathrm{Na}$ MOR-EE was prepared by stirring Pd/H-MOR ( $2 \mathrm{~g})$ in sodium bicarbonate solution $(1 \mathrm{M}, 200 \mathrm{ml})$ for $2 \mathrm{~h}$. The catalyst was then treated identically to $\mathrm{Pd} / \mathrm{Na}$ MOR. For the conventional synthesis route, H-MOR $(5 \mathrm{~g})$ was exchanged three times with sodium nitrate $(1 \mathrm{M}, 100 \mathrm{ml})$, washed with deionized water, dried at 120 ${ }^{\circ} \mathrm{C}$ for $6 \mathrm{~h}$, and calcined at $500{ }^{\circ} \mathrm{C}$ for $2 \mathrm{~h}$. The solid was then ion-exchanged with tetraammine palladium nitrate solution ( $\mathrm{pH}=7$ for $\mathrm{Pd} / \mathrm{NaH}-\mathrm{MOR}-1$ and $\mathrm{pH}=5$ for $\mathrm{Pd} / \mathrm{NaH}-\mathrm{MOR}-2$ ), dried, and calcined as described above. $\mathrm{Pd} / \mathrm{Al}_{2} \mathrm{O}_{3}$ was synthesized by wet impregnation. Alumina powder (SASOL Puralox UF 5/230) was stirred for $6 \mathrm{~h}$ at $80^{\circ} \mathrm{C}$ with a palladium nitrate solution (Alfa Aesar) corresponding to $1 \mathrm{wt} \%$ loading of palladium. After the solvent was slowly evacuated, the solid was dried and calcined following the same protocol as for $\mathrm{Pd} / \mathrm{H}-\mathrm{MOR}$.

Characterization. The $\mathrm{Si} / \mathrm{Al}$ ratio, palladium, and sodium contents of the catalysts were determined by inductively coupled plasma optical emission spectrometry (ICP-OES) using a Varian VISTA Pro AX instrument. STEM images were taken with a high-angle annular dark-field detector (HAADF) on an aberration-corrected Hitachi HD-2700 microscope operated at an acceleration voltage of $200 \mathrm{kV}$. QuickEXAFS data were acquired in transmission mode at the Pd K-edge (24.35 $\mathrm{keV}$ ) at the SuperXAS beamline of the Swiss Light Source (SLS, Paul Scherrer Institute) at the time resolution of $1 \mathrm{~s}$. The catalytic activity was monitored by online mass-spectrometer. The Fourier transformation of the $\mathrm{k}^{2}$-weighted EXAFS functions was performed in the range $3-11 \AA^{-1}$. Data reduction was performed using the Athena software package ${ }^{48}$. A Bruker D8 Advance AXS diffractometer with $\mathrm{Cu} \mathrm{Ka}$ radiation was used to obtain powder XRD patterns in the $2 \theta$ range from $10^{\circ}$ to $60^{\circ}$. Solid-state magic angle spinning nuclear magnetic resonance (MAS NMR) ${ }^{27} \mathrm{Al}$ spectra were recorded at $10 \mathrm{kHz}$ (1024 accumulations) on a Bruker Avance $400 \mathrm{MHz}$ spectrometer with ammonium aluminum sulfate dodecahydrate $\left(\mathrm{AlNH}_{4}\left(\mathrm{SO}_{4}\right)_{2} \cdot 12 \mathrm{H}_{2} \mathrm{O}\right)$ as a reference. The textural properties of the support were characterized by argon physisorption at $77 \mathrm{~K}$ using a Quantachrome Autosorb 1 instrument after degassing at $300^{\circ} \mathrm{C}$ for $24 \mathrm{~h}$ to remove water and other adsorbed species. The specific surface area was calculated using the

Brunauer-Emmett-Teller (BET) method. Pore size distribution in the range from 0.5 to $50 \mathrm{~nm}$ was calculated by fitting the isotherms using the method of non-linear density functional theory (NLDFT) from the instrument software package. Diffuse reflectance Fourier transform infrared (DRIFT) spectra were measured using a Bruker Vertex 70 spectrometer equipped with a Praying Mantis mirror unit and a liquid nitrogen cooled MCT detector. All DRIFT spectra were collected by accumulating 100 scans at $4 \mathrm{~cm}^{-1}$ resolution and a scanner velocity of $80 \mathrm{kHz}$. Prior to acquisition of the background spectrum, the sample was dehydrated at $350{ }^{\circ} \mathrm{C}$ for 1 h. $\mathrm{NH}_{3}$ adsorption was followed at $100{ }^{\circ} \mathrm{C}$ during exposure of the catalyst to 500 ppm of ammonia in nitrogen at the flow rate of $20 \mathrm{ml} \mathrm{min}^{-1} . \mathrm{NH}_{3}$ desorption was monitored while the temperature of the sample was increased from 100 to $300^{\circ} \mathrm{C}$ in nitrogen flow.

Data availability. The datasets generated and analyzed during the current study are archived on the internal servers of the Paul Scherrer Institut and are available from the corresponding authors on reasonable request.

Received: 19 March 2018 Accepted: 21 May 2018

Published online: 29 June 2018

\section{References}

1. Cargnello, M. et al. Exceptional activity for methane combustion over modular $\mathrm{Pd} @ \mathrm{CeO}_{2}$. Subunits on functionalized $\mathrm{Al}_{2} \mathrm{O}_{3}$. Science 337, 713-717 (2012).

2. Gelin, P. \& Primet, M. Complete oxidation of methane at low temperature over noble metal based catalysts: a review. Appl. Catal. B: Environ. 39, 1-37 (2002).

3. Colussi, S. et al. Nanofaceted Pd-O sites in Pd-Ce surface superstructures: enhanced activity in catalytic combustion of methane. Angew. Chem. Int. Ed. 48, 8481-8484 (2009).

4. Choudhary, T. V., Banerjee, S. \& Choudhary, V. R. Catalysts for combustion of methane and lower alkanes. Appl. Catal. A: Gen. 234, 1-23 (2002).

5. Bielaczyc, P., Woodburn, J. \& Szczotka, A. An assessment of regulated emissions and $\mathrm{CO}_{2}$ emissions from a European light-duty CNG-fueled vehicle in the context of Euro 6 emissions regulations. Appl. Energy 117, 134-141 (2014).

6. Allen, G. Biogeochemistry: rebalancing the global methane budget. Nature 538, 46-48 (2016)

7. Lelieveld, J. Climate change: a nasty surprise in the greenhouse. Nature $\mathbf{4 4 3}$ 405-406 (2006).

8. Schwietzke, S. et al. Upward revision of global fossil fuel methane emissions based on isotope database. Nature 538, 88-91 (2016).

9. Montzka, S. A., Dlugokencky, E. J. \& Butler, J. H. Non- $\mathrm{CO}_{2}$ greenhouse gases and climate change. Nature 476, 43-50 (2011)

10. Roth, D., Gelin, P., Tena, E. \& Primet, M. Combustion of methane at low temperature over $\mathrm{Pd}$ and $\mathrm{Pt}$ catalysts supported on $\mathrm{Al}_{2} \mathrm{O}_{3}, \mathrm{SnO}_{2}$ and $\mathrm{Al}_{2} \mathrm{O}_{3}$ grafted $\mathrm{SnO}_{2}$. Top. Catal. 16, 77-82 (2001).

11. Zhang, S. et al. Dynamic structural evolution of supported palladium-ceria core-shell catalysts revealed by in situ electron microscopy. Nat. Commun. 6, 7778 (2015).

12. Yoshida, H., Nakajima, T., Yazawa, Y. \& Hattori, T. Support effect on methane combustion over palladium catalysts. Appl. Catal. B: Environ. 71, 70-79 (2007).

13. Descorme, C., Gelin, P., Lecuyer, C. \& Primet, M. Palladium-exchanged MFI type zeolites in the catalytic reduction of nitrogen monoxide by methane Influence of the $\mathrm{Si} / \mathrm{Al}$ ratio on the activity and the hydrothermal stability. Appl. Catal. B: Environ. 13, 185-195 (1997).

14. Setiawan, A. et al. Towards understanding the improved stability of palladium supported on TS-1 for catalytic combustion. Phys. Chem. Chem. Phys. 18, 10528 (2016).

15. Gholami, R., Alyani, M. \& Smith, K. J. Deactivation of Pd catalysts by water during low temperature methane oxidation relevant to natural gas vehicle converters. Catalysts 5, 561-594 (2015).

16. Lou, Y. et al. Low-temperature methane combustion over Pd/H-ZSM-5: active Pd sites with specific electronic properties modulated by acidic sites of H-ZSM-5. ACS Catal. 6, 8127-8139 (2016). 
17. Tao, F. F. et al. Understanding complete oxidation of methane on spinel oxides at a molecular level. Nat. Commun. 6, 7798 (2015).

18. Adamski, A., Kaczmarczyk, J., Kotarba, A., Stelamchowski, P. \& Sojka, Z. Multicomponent oxide catalyst for low-temperature oxidation of methane and the method for preparat ion thereof. International patent application 025274 A1 (2014).

19. Tissler, A. et al. Zeolite catalysts containing titanium for the oxidation of methane in exhaust gas streams. US patent application 0310895 A1 (2016).

20. Li, Y. \& Armor, J. N. Catalytic combustion of methane over palladium exchanged zeolites. Appl. Catal. B: Environ. 3, 275-282 (1994).

21. Montes de Correa, C. \& Villa, A. L. Combustion of methane over palladium ZSM-5 and mordenite catalysts. Appl. Catal. B: Environ. 10, 313-323 (1996).

22. Wang, N. et al. In situ confinement of ultrasmall Pd clusters within nanosized silicalite-1 zeolite for highly efficient catalysis of hydrogen generation. J. Am. Chem. Soc. 138, 7484-7487 (2016).

23. Gu, J. et al. Platinum nanoparticles encapsulated in MFI zeolite crystals by a two-step dry gel conversion method as a highly selective hydrogenation catalyst. ACS Catal. 5, 6893-6901 (2015).

24. Maeda, H. et al. Activity of palladium loaded on zeolites in the combustion of methane. Appl. Catal. A: Gen. 163, 59-69 (1997).

25. Okumura, K., Shinohara, E. \& Niwa, M. Pd loaded on high silica beta support active for the total oxidation of diluted methane in the presence of water vapor. Catal. Today 117, 577-583 (2006).

26. Okumura, K., Matsumoto, S., Nishiaki, N. \& Niwa, M. Support effect of zeolite on methane combustion activity of palladium. Appl. Catal. B: Environ. 40, 151-159 (2003).

27. Tissler, A. et al. Platinum/palladium zeolite catalyst. US patent application 0059226 A1 (2016)

28. Petrov, A. W., Ferri, D., Tarik, M., Kröcher, O. \& van Bokhoven, J. A. Deactivation aspects of methane oxidation catalysts based on palladium and ZSM-5. Top. Catal. 60, 123-130 (2016).

29. Zhai, Y. et al. Alkali-stabilized Pt- $\mathrm{OH}_{\mathrm{x}}$ species catalyze low-temperature water-gas shift reactions. Science 329, 1633-1636 (2010).

30. Okumura, K. et al. Energy-dispersive XAFS studies on the spontaneous dispersion of $\mathrm{PdO}$ and the formation of stable Pd clusters in zeolites. J. Phys. Chem. B 108, 6250-6255 (2004).

31. Fodor, D., Ishikawa, T., Krumeich, F. \& van Bokhoven, J. A. Synthesis of single crystal nanoreactor materials with multiple catalytic functions by incipient wetness impregnation and ion exchange. Adv. Mater. 27, 1919-1923 (2015).

32. Tromp, M. et al. Influence of the generation of mesopores on the hydroisomerization activity and selectivity of $\mathrm{n}$-hexane over $\mathrm{Pt} /$ mordenite. J. Catal. 190, 209-214 (2000)

33. Giudici, R., Kouwenhoven, H. W. \& Prins, R. Comparison of nitric and oxalic acid in the dealumination of mordenite. Appl. Catal. A: Gen. 203, 101-110 (2000).

34. Viswanadham, N. \& Kumar, M. Effect of dealumination severity on the pore size distribution of mordenite. Microporous Mesoporous Mater. 92, 31-37 (2006).

35. Janssen, A. H., Koster, A. J. \& de Jong, K. P. Three-dimensional transmission electron microscopic observations of mesopores in dealuminated zeolite $\mathrm{Y}$. Angew. Chem. Int. Ed. 40, 1102-1104 (2001).

36. Serrano, D. P., Escola, J. M. \& Pizarro, P. Synthesis strategies in the search for hierarchical zeolites. Chem. Soc. Rev. 42, 4004-4035 (2013).

37. Na, K., Yoon, J. \& Somorjai, G. A. Control of model catalytic conversion reaction over Pt nanoparticle supported mesoporous BEA zeolite catalysts. Catal. Today 265, 225-230 (2016).

38. Li, L., Abild-Pedersen, F., Greeley, J. \& Nørskov, J. K. Surface tension effects on the reactivity of metal nanoparticles. J. Phys. Chem. Lett. 6, 3797-3801 (2015).

39. Miller, J. T. et al. The effect of gold particle size on AuAu bond length and reactivity toward oxygen in supported catalysts. J. Catal. 240, 222-234 (2006).

40. Ciuparu, D., Lyubovsky, M. R., Altman, E., Pfefferle, L. D. \& Datye, A. Catalytic combustion of methane over palladium-based catalysts. Catal. Rev. 44, 593-649 (2002).

41. Xiong, $\mathrm{H}$. et al. Metastable $\mathrm{Pd} \leftrightarrow \mathrm{PdO}$ structures during high temperature methane oxidation. Catal. Lett. 147, 1095-1103 (2017).
42. Chin, Y.-H. \& Iglesia, E. Elementary steps, the role of chemisorbed oxygen, and the effects of cluster size in catalytic $\mathrm{CH}_{4}-\mathrm{O}_{2}$ reactions on palladium. $J$. Phys. Chem. C 115, 17845-17855 (2011).

43. Chin, Y.-H., Buda, C., Neurock, M. \& Iglesia, E. Consequences of metal-oxide interconversion for $\mathrm{C}-\mathrm{H}$ bond activation during $\mathrm{CH}_{4}$ reactions on $\mathrm{Pd}$ catalysts. J. Am. Chem. Soc. 135, 15425-15442 (2013).

44. Gabasch, H. et al. Methane oxidation on Pd(111): in situ XPS identification of active phase. J. Phys. Chem. C 111, 7957-7962 (2007).

45. Han, J., Zemlyanov, D. Y. \& Ribeiro, F. H. Catalytic combustion of methane on palladium single crystals. Catal. Today 117, 506-513 (2006).

46. Chin, Y.-H., García-Diéguez, M. \& Iglesia, E. Dynamics and thermodynamics of Pd-PdO phase transitions: effects of Pd cluster size and kinetic implications for catalytic methane combustion. J. Phys. Chem. C 120, 1446-1460 (2016).

47. Arosio, F., Colussi, S., Trovarelli, A. \& Groppi, G. Effect of alternate $\mathrm{CH}_{4}$ reducing/lean combustion treatments on the reactivity of fresh and Spoisoned $\mathrm{Pd} / \mathrm{CeO}_{2} / \mathrm{Al}_{2} \mathrm{O}_{3}$ catalysts. Appl. Catal. B: Environ. 80, 335-342 (2008).

48. Ravel, B. \& Newville, M. ATHENA, ARTEMIS, HEPHAESTUS: data analysis for X-ray absorption spectroscopy using IFEFFIT. J. Synchrotron Radiat. 12, 537-541 (2005).

\section{Acknowledgments}

The authors thank the Paul Scherrer Institut for the financial support and for granting access to the Swiss Light Source, Dr. R. Verel (ETH Zurich) for assistance with NMR measurements, and Mrs. Silvia Köchli (Paul Scherrer Institut) for elemental analysis.

\section{Author contributions}

A.W.P., D.F., O.K., and J.A.v.B. conceived the idea for the study. A.W.P. prepared the catalysts, collected the catalytic data, and performed characterization. All authors contributed to analysis of the data and design of the experiments. F.K. performed STEM characterization and helped to interpret the micrographs. M.N. assisted with XAS measurements and XAS data analysis. D.F., O.K., and J.A.v.B. supervised the project. A.W.P. wrote the draft and all authors took part in improving the manuscript.

\section{Additional information}

Supplementary Information accompanies this paper at https://doi.org/10.1038/s41467018-04748-x.

Competing interests: The authors declare no competing interests.

Reprints and permission information is available online at http://npg.nature.com/ reprintsandpermissions/

Publisher's note: Springer Nature remains neutral with regard to jurisdictional claims in published maps and institutional affiliations.

Open Access This article is licensed under a Creative Commons Attribution 4.0 International License, which permits use, sharing, adaptation, distribution and reproduction in any medium or format, as long as you give appropriate credit to the original author(s) and the source, provide a link to the Creative Commons license, and indicate if changes were made. The images or other third party material in this article are included in the article's Creative Commons license, unless indicated otherwise in a credit line to the material. If material is not included in the article's Creative Commons license and your intended use is not permitted by statutory regulation or exceeds the permitted use, you will need to obtain permission directly from the copyright holder. To view a copy of this license, visit http://creativecommons.org/ licenses/by/4.0/.

(C) The Author(s) 2018 